\title{
Food security in rural Burkina Faso: the importance of consumption of own-farm sourced food versus purchased food
}

\author{
Simon Fraval ${ }^{1,2^{*}}$ (D) Viviane Yameogo ${ }^{3}$, Augustine Ayantunde ${ }^{3}$, James Hammond ${ }^{1}$, Imke J. M. de Boer ${ }^{2}$, \\ Simon J. Oosting ${ }^{2}$ and Mark T. van Wijk ${ }^{1}$
}

\begin{abstract}
Background: The number of undernourished people and the risk of micro-nutrient deficiency remain high in subSaharan Africa (SSA). Decades of policy designed to reverse the trends of food insecurity have illustrated that the causal pathways of intervention to end-point outcomes, such as nutrition, are not necessarily straightforward. Utilising proxies for dimensions of food security, this study investigates the relative importance of different pathways to food security in two subtly contrasting communities in the Sahelian and Sudanian Savanna zones of Burkina Faso.

Results: In Yatenga province, approximately 31\% of households were classified as 'severely food insecure' in the 'lean' period. In contrast, over $84 \%$ of households sampled in Seno province were classified as being 'severely food insecure' in the 'lean' period. There were statistically significant associations between food security indicators and off-farm income, farm income and production diversity. The source of income had significantly different associations with diet diversity in the two provinces. In Yatenga province, higher gross farm income in the absence of off-farm income was predicted to result in more diverse diets; in Seno province, however, gross farm income was only predicted to result in more diverse diets when households are also earning off-farm income.

Conclusions: Our analysis shows that households were most differentiated by income generating pathways to food security in the 'lean' period. This finding should not detract from the essential role played by home-produced foods in improving food security. Rather, market-orientated agriculture and production for home consumption, as shown by households in this study, can be combined as part of a more resilient livelihood strategy. Policy needs to be targeted towards agro-ecological conditions, as well as socioeconomic factors in order to facilitate improved on-farm income, farm resilience and off-farm employment opportunities.
\end{abstract}

Keywords: Nutrition-sensitive interventions, Market-orientated agriculture, Resilient systems

\section{Background}

The decade-long decline in global chronic undernourishment has been reversed in recent years. The prevalence of chronic undernourishment in sub-Saharan Africa (SSA) has almost returned to 2005 levels (24\% of the

\footnotetext{
*Correspondence: simon.fraval@outlook.com

1 International Livestock Research Institute (ILRI), Naivasha Road, PO Box 30709, Nairobi 00100, Kenya

Full list of author information is available at the end of the article
}

population) after reaching a low of $21 \%$ of the population in 2015-equating to approximately 232 million people (23\% of the population) unable to meet their energy needs in 2017 [1]. There is also a high risk of micro-nutrient deficiency in the broader population, termed 'hidden hunger' (another important aspect of malnutrition). Joy et al. [2] provide startling estimates of deficiency risks for calcium ( $>50 \%)$, zinc $(40 \%)$, selenium $(28 \%)$ and iodine $(19 \%)$ in the African population. The individual and societal implications for such nutritional deficiencies are

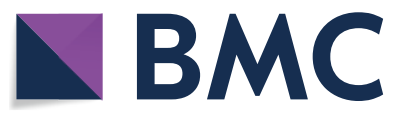

(c) The Author(s) 2020. This article is licensed under a Creative Commons Attribution 4.0 International License, which permits use, sharing, adaptation, distribution and reproduction in any medium or format, as long as you give appropriate credit to the original author(s) and the source, provide a link to the Creative Commons licence, and indicate if changes were made. The images or other third party material in this article are included in the article's Creative Commons licence, unless indicated otherwise in a credit line to the material. If material is not included in the article's Creative Commons licence and your intended use is not permitted by statutory regulation or exceeds the permitted use, you will need to obtain permission directly from the copyright holder. To view a copy of this licence, visit http://creativeco mmons.org/licenses/by/4.0/. The Creative Commons Public Domain Dedication waiver (http://creativecommons.org/publicdomain/ zero/1.0/) applies to the data made available in this article, unless otherwise stated in a 
borne disproportionately by the rural population, indicated by the consistently higher prevalence of stunting in rural SSA [3] - particularly those in the Sahel, such as northern Burkina Faso [4].

Given the persistence of undernourishment and hidden hunger, nutrition-specific and nutrition-sensitive interventions have been implemented across SSA [5]. Agricultural interventions have an intuitive link with the most nutritionally vulnerable of communities, particularly those with limited off-farm employment options. The causal pathways from intervention to end-point outcomes, such as nutrition, are less straightforward [6]. Increased incomes and energy availability, for example, are necessary for alleviating undernourishment, but not sufficient for addressing 'hidden hunger' [7-11]. A greater understanding of these pathways is needed, particularly given the UN's ambitious target of 'zero hunger' by 2030 (as part of the Sustainable Development Goals) within the context of stagnating aid flows [12], the low levels of research and development spending in SSA [13] and the food system transformations taking place across SSA [14-17].

One challenge in assessing the pathways from agricultural intervention to nutrition outcomes relates to monitoring the food security status of the population. In the past there was a proliferation of food security indicators, resulting in inconsistencies in scope, method and spatio-temporal coverage [18]. As a multidimensional phenomenon, the scope of food security monitoring can be broad-encompassing multiple dimensions, using an integrative assessment-or can be narrow, focusing on one dimension with a limited number of indicators. Aggregating evidence into indicators and then indicators into composite indicators, involves trade-offs with information richness and analytical tractability. Each of the steps involved in the indicator development process can have a bearing on the quality, interpretation and repeatability of the metric $[19,20]$. To avoid the loss of information associated with composite indicators, we focus on one dimension of food security-food accessintegrating multiple indicators in discussion.

The methods for evaluating food access and micronutrient deficiencies have traditionally been time-consuming and invasive. More recently, however, proxies have been introduced to enable wide-scale monitoring and evaluation. Food insecurity of access metrics and diet diversity scores (to a greater extent) have been assessed against diet quality and adequacy ratios, and have emerged as reliable proxies (evident in [21-27]. In the one case where Household Diet Diversity Score (HDDS) was not associated with diet quality or adequacy ratios, an association was instead identified with Household Food Insecurity of Access Score/Prevalence (HFIAS/ HFIAP; [28]. As HFIAS/HFIAP and HDDS represent different aspects of food security, both metrics are adopted in the present study.

Utilising these proxies for food insecurity, a growing body of literature has taken shape around the question of what differentiates those that are food insecure from those that are more food secure in high-risk communities around the world. Jones [29] present a conceptual framework, hypothesising that on-farm crop species richness is associated with diet quality and diversity through ownfarm consumption and market-orientated production, generating income for food expenditures (Fig. 1). It is hypothesised that these two channels are mediated by agricultural productivity, markets, infrastructure, wealth, gender dynamics and food purchasing behaviour. Species

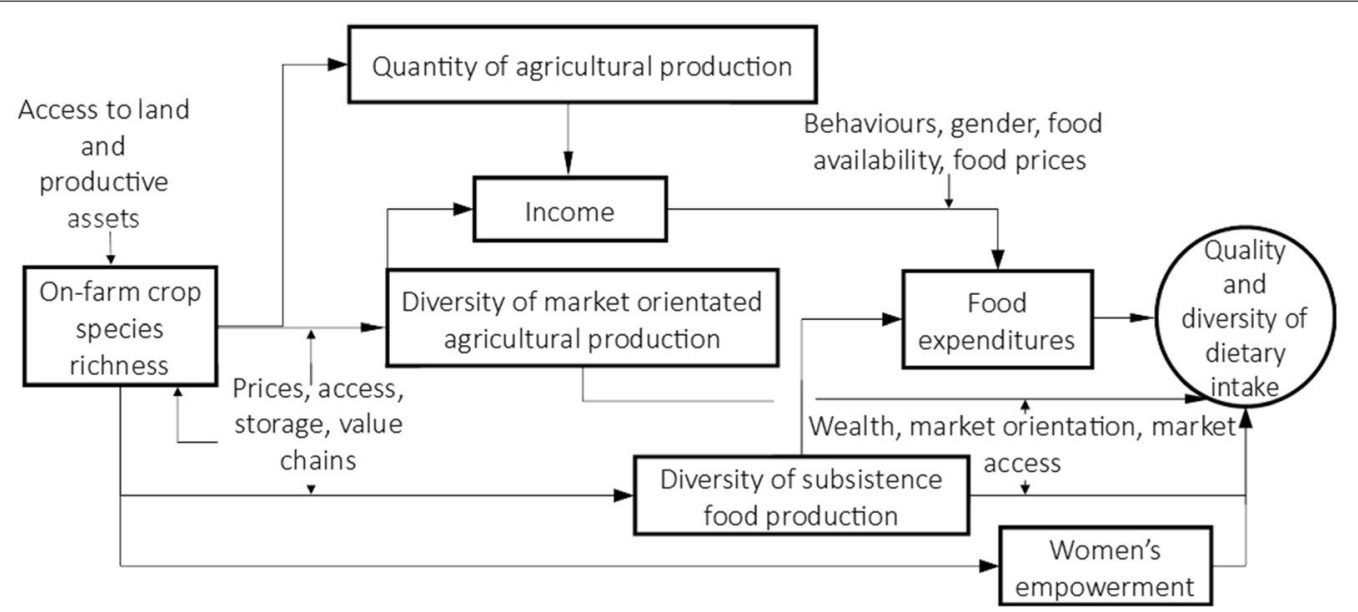

Fig. 1 Conceptual framework of hypothesised causal linkages between on-farm crop species richness and the quality and diversity of household diets. Adapted from [29] 
richness is also hypothesised to have a positive influence on agricultural productivity and resilience to shocks.

There has been some contention in the literature about the relationships between subsistence production, market-orientated production and food security. Powell et al. [30] provide a summary of six studies that identify positive relationships between the diversity of crops cultivated and diet diversity. More recently, several studies-largely focused on SSA-have explored these relationships in greater detail. Income, and thus purchased foods, has been found to be highly associated with dietary diversity in the majority of these studies, whereas food from subsistence production, while also significant, had a limited relationship with dietary diversity ([3137]). Jones [29] and M'Kaibi et al. [38] in comparison, emphasised the positive relationship farm production has with food security indicators (diet diversity and micro/ macro-nutrient intake in [29]; nutrient adequacy ratios and HFIAS in [38]). In the most geographically diverse study to date, the role of farm production on food security was found to be of varying importance depending on market opportunities, and the relationship was found to be non-linear [34]. In the existing literature, however, there is a limitation that the relationships between subsistence production, market-orientated production and food security have been modelled indirectly and often at one or two points of time in the year.

This present study seeks to improve our understanding of the associations between improved food security and household-farm attributes in vulnerable rural communities. We do so by characterising farm systems, household demographics and food security status in subtly contrasting communities in drought prone regions of Burkina Faso. Food security indicators were enumerated for two periods to account for the temporal variability throughout the year. Diet diversity was disaggregated by channel of access to better understand food sourcing behaviour. With this approach we address the questions of: (a) what are the differentiating attributes of more food secure households, and more specifically (b) what are the roles of subsistence (own-farm sourced) and food purchases in improving access to sufficient and diverse nutrition? This study, therefore, contributes to the discussion of the drivers of food security of access, using a methodology that accounts for the temporal variability throughout the year.

\section{Results}

Household characteristics and welfare in the two provinces There were significant differences in the livelihoods of households between the two provinces. Table 1 compares provinces across a range of variables directly and indirectly related to human nutrition (full distributions shown in Additional file 1: Fig. S1). These variables are presented in the table as follows: resources (adult equivalents, land and livestock ownership), income (including gendered control), wealth (PPI), crop production (diversity, yields, market participation), human energy adequacy (from consumption of own-produced crop and livestock products), and livestock production (diversity, market participation and protein adequacy). There were notable differences between provinces in household demographics, land area, land use, market participation, energy/protein adequacy, and income (significant differences indicated in column 4 of Table 1). This section describes the variability and differences in livelihoods.

Household demographics differed across the two provinces. Households in Yatenga province tended to have more inhabitants and therefore, greater potential labour availability and marginally higher nutritional requirements. The household head in Yatenga province was generally older $(\mu=57, \mathrm{sd}=12)$ than in Seno province $(\mu=50, \mathrm{sd}=13$; results not shown), and for the vast majority (>93\%) of households in both provinces-the household head was male (results not shown).

Households in Yatenga province had larger parcels of land (median of 5 ha) than in Seno province (3.5 ha; Table 1), and the majority of households in both provinces utilised their land for mixed crop-livestock systems. Livestock holdings were similar across provinces, with medians of approximately five tropical livestock units (TLUs); five households in Seno province, however, kept between 25 and 85 TLUs (results not shown). Land was cultivated in the 'flush' period with sorghum (Bicolor L.) and millet (Pennisetum glaucum L. and Eleusine coracana L.) by almost all farmers; cowpeas (Vigna unguiculata L.) were cultivated by the majority of farmers ( $99 \%$ in Yatenga and 68\% in Seno); sesame (Sesamum indicum L.) and maize (Zea mays L.) was cultivated by approximately a quarter of farmers; groundnut (Arachis hypogaea L.) was cultivated by the majority (96\%) of households in Yatenga province and some households in Seno province (9\%); rice (Oryza spp.) production was exclusively in Yatenga province, largely in the Oula department. Vegetable cultivation was also more prevalent in Yatenga, with $20 \%$ of households cultivating up to 1.5 hectares (results not shown). As such, there was greater crop diversity in Yatenga province when compared to Seno province (Table 1).

Yields per hectare of staple crops were lower than the rain-water limited yield potential. Maize was the highest yielding staple crop, followed by the more commonly cultivated staples of sorghum and then millet. Crop yields for these three staple crops were marginally lower in Yatenga when compared to Seno (difference in millet yield was not statistically significant; Table 1). Households differed in their levels of practice adoption. 
Table 1 Summary of resources and farming activity of households (median and IQR)

\begin{tabular}{|c|c|c|c|}
\hline & Yatenga $(n=200)$ & Seno $(n=200)$ & \\
\hline Household inhabitants (adult equivalents) & $10.4(5.4)$ & $6.8(5.3)$ & * \\
\hline Land area (ha) & $5.0(4.1)$ & $3.5(3.0)$ & * \\
\hline Livestock holdings (TLUs) ${ }^{\mathrm{a}}$ & $5.20(4.8)$ & $5.1(9.0)$ & NS \\
\hline Off-farm income (USD year $\left.{ }^{-1}\right)^{b}$ & $83.25(451.62)$ & $74.92(416.24)$ & NS \\
\hline Crop gross income (USD year $\left.{ }^{-1}\right)^{\mathrm{b}}$ & $354.56(637.55)$ & $0.00(8.11)$ & * \\
\hline Live animal net income $\left(\text { USD year }{ }^{-1}\right)^{b}$ & $12.49(97.90)$ & $60.84(248.72)$ & * \\
\hline Animal product net income (USD year $\left.{ }^{-1}\right)^{b}$ & $0(0)$ & $0(0)$ & NS \\
\hline Relative female control (\% income year ${ }^{-1}$ ) & $0(2)$ & $0(0)$ & * \\
\hline Progress out of Poverty Index score & $38(14)$ & $31(16)$ & * \\
\hline Number of crop species & $5(2)$ & $3(2)$ & * \\
\hline Crop production diversity score & $2(1)$ & $2(0)$ & * \\
\hline Sorghum yield $\left(\mathrm{kg} \mathrm{ha}^{-1}\right)$ & $225.0(338.0)$ & $250.0(250.0)$ & * \\
\hline Millet yield $\left(\mathrm{kg} \mathrm{ha}^{-1}\right)$ & $184.0(350.0)$ & $217.0(350.0)$ & NS \\
\hline Maize yield $\left(\mathrm{kg} \mathrm{ha}^{-1}\right)$ & $650(985.0)$ & $720.0(725.0)$ & * \\
\hline Crop market participation (\% of total calories produced year ${ }^{-1}$ ) & $41(26)$ & $0(1)$ & * \\
\hline Energy adequacy (crop and livestock consumed—-kcal adult equivalent ${ }^{-1}$ ) & $1.00(1.1)$ & $0.8(0.7)$ & * \\
\hline Number of livestock species & $4(2)$ & $4(2)$ & NS \\
\hline Livestock production diversity score & $1(0)$ & $2(1)$ & NS \\
\hline Livestock market participation (\% of protein produced year ${ }^{-1}$ ) & $0(0)$ & $0(3)$ & NS \\
\hline Protein adequacy (livestock protein adult equivalent ${ }^{-1}$ adequacy ratio) & $0.02(0.02)$ & $0.15(0.27)$ & * \\
\hline
\end{tabular}

$\mathrm{NS} \mathrm{Cl}$ crosses zero or model does not converge

${ }^{*} \mathrm{Cl}$ does not cross zero. Provinces have differing central tendencies

a Oxen $=1.42$, cows $=1$, camel $=1.1$, horse $=0.9$, donkey $=0.8$, pigs $=0.3$, sheep and goats $=0.2$, chickens $=0.04$

b 1 CFA $=0.001665$ USD

Improved seeds, fertiliser and irrigation were more readily adopted in Yatenga province; and, value addition was common in both provinces (Additional file 1: Tables S2 and S3). As a proxy for the diversity of cash crop yield differences, Fig. 2 presents crop income by adopted practices and province. Crop income was significantly higher for households in Yatenga province that adopted irrigation, fertilisers and/or improved seeds (CI does not cross zero; $t$ test alternative). In terms of livestock, there was a low level of adoption of improved livestock breeds in both Yatenga and Seno provinces.

Larger land sizes and higher rates of crop market participation in Yatenga province resulted in a higher median energy adequacy ratio and higher median crop income,
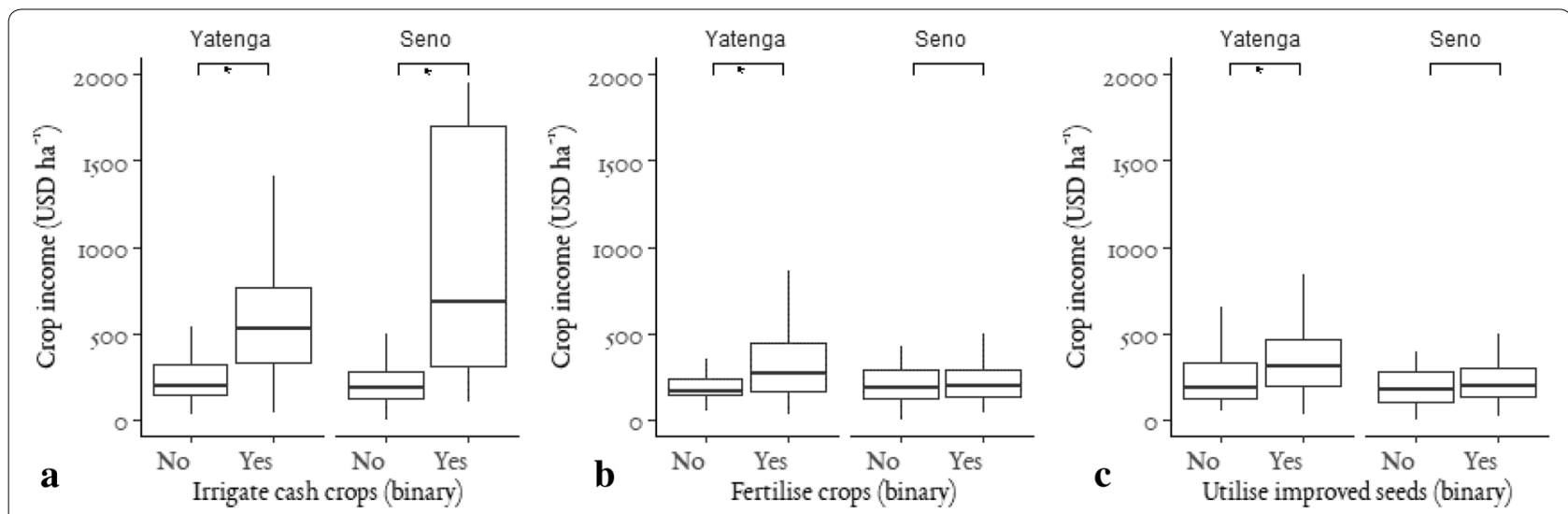

Fig. 2 Gross crop income by practice adoption (irrigation, fertiliser and improved seeds) and province. *Groups have differing central tendencies 
in comparison to Seno (Table 1). The low instance of crop market participation in Seno province (median zero in Table 1) stems from a focus on livestock rearing and smaller land sizes. In Yatenga province, households at the median were potentially self-sufficient in energy needs; in Seno province, the median energy adequacy ratio was below sufficiency, with $80 \%$ of annual energy needs met by home consumption of crops and animal sourced foods. Livestock market participation was more common in Seno province, as was consumption of home-produced livestock products-as shown in the higher adequacy ratio of protein from animal sources and higher median income from livestock products (Table 1). Other sources of farm income were limited, with 13 households generating income from timber products, seven households generating income from fish sales and three households renting out land.

Off-farm income was common across provinces (67\% of households in Yatenga, 57\% of households in Seno), with the majority earning under US\$ 500 per household per annum. For those that did earn off-farm income, the central tendency of earnings was similar across provinces (median of US\$ 296 in Yatenga and US\$ 375 in Seno). Households in Yatenga generally had higher gross incomes, yet significantly less income from live animals (Table 1). Control of income did not differ significantly by province, where the majority $(85 \%)$ of households had less than $10 \%$ of income controlled by females. Households in Yatenga province tended to have a higher Progress out of Poverty Indicator score (PPI).

\section{Determinants of food (in)security of access}

Households had differing perceptions of the severity and duration of food insecurity. In Yatenga province, the most common period of perceived shortage was between February and October (27\% of households). In Seno province, $43 \%$ of households perceived a shortage of food between June and October. Many households perceived that they had just enough food throughout the year (27\% in Yatenga and 20\% in Seno), and a few households considered themselves to be food secure throughout the year ( $8 \%$ in Yatenga and $6.5 \%$ in Seno). There was only one household per province that perceived a shortage in the period between November and February, where the majority of households considered themselves to be secure during this time. For the following analysis, the 'flush' period can be considered as this period between November and February and the 'lean' period as being more variable in duration and severity-between February and October. Aid in the form of food or cash transfers was distributed in the study area. In Yatenga province, $40 \%$ of households received aid, whereas in Seno province, only two households received aid. The most common period of aid provision was between June and October (results not shown).

The majority of households in the 'lean' period were classified as either 'severely food insecure' or 'moderately food insecure' using the Household Food Insecurity Access Prevalence (HFIAP) indicator (Additional file 1: Table S1). In Yatenga province, approximately $31 \%$ of households were classified as 'severely food insecure' in the 'lean' period, $41 \%$ as 'moderately food insecure', $17 \%$ as 'mildly food insecure' and $10 \%$ as 'food secure'. The food security status of households in Seno province was worse, with over $84 \%$ of households classified as being 'severely food insecure' in the 'lean' period.

The HFIAS variable was modelled as a function of several farm-household variables, receipt of aid and province of residence. There was a positive association between gross income and a higher food security of access status (i.e. not severely food insecure) in both provinces in the 'lean' period; this association was stronger in Yatengaindicated by the significant interaction term (Table 2). The number of livestock species kept was positively associated with a higher food security of access status in the 'lean' period. The number of crop species and whether the household received aid were not associated with food security of access in the 'lean' period (Table 2). Furthermore, there were no statistically significant associations identified for literacy, gender of household head, household inhabitants, market participation, wealth (PPI; variable removed from regression), relative female control of income, or the number of crop species cultivated.

\section{Determinants of household diet diversity}

The Household Diet Diversity Score (HDDS) differed across periods and provinces. In general, diets were more diverse in the 'flush' period and households in Yatenga province tended to have more diverse diets in the 'lean' period than households in Seno province (intercepts and province coefficient in Table 3 and medians in Table 4). In both sites and periods, the majority of households sourced cereals, 'beans, legumes, nuts and seeds' and sugar. In Yatenga province, vegetables, fish, fruit and 'fats and oils' were consumed by the majority of households. Meat and 'roots and tubers' were consumed by households in Yatenga with higher diet diversity counts. Milk and eggs were consumed in Yatenga by a limited number of households. In Seno province, milk was consumed by a majority of households. Meat, and to a lesser extent, eggs were consumed by more households in Seno province when compared to Yatenga province-both in the 'lean' and 'flush' periods. Vegetables, fruits, 'roots and tubers', fish and 'fats and oils' were consumed by fewer households in comparison to Yatenga province. In Seno 
Table 2 Household Food Insecurity Access (logistic regressions)

\begin{tabular}{|c|c|c|}
\hline & Lean period $^{\mathrm{a}}$ & Flush period $^{a}$ \\
\hline Intercept & $-2.41(-5.14,0.23)$ & $1.01(-1.96,4.80)$ \\
\hline Household head literacy ${ }^{b}$ & $0.17(-0.44,0.76)$ & $0.42(-0.13,0.97)$ \\
\hline Household head gender & $0.00(-1.03,1.00)$ & $0.06(-0.86,0.97)$ \\
\hline Household inhabitants (adult eq.) & $-0.2(-0.10,0.06)$ & $0.03(-0.05,0.10)$ \\
\hline Crop market participation (\% kcal sold) & $0.27(-0.10,0.65)$ & $0.03(-0.38,0.32)$ \\
\hline Livestock market participation (\% kcal sold) & $0.21(-0.08,0.49)$ & $0.16(-0.42,0.11)$ \\
\hline Gross income ('000 USD year' $\left.{ }^{-1}\right)$ & $0.26(0.01,0.54)^{*}$ & $0.17(0.02,0.41)^{*}$ \\
\hline Relative female control ( $>40 \%$ income year ${ }^{-1}$ ) & $-0.96(-2.00,0.05)$ & $0.34(-1.16,0.47)$ \\
\hline Number of crop species & $0.05(-0.23,0.33)$ & $0.04(-0.24,0.31)$ \\
\hline Number of livestock species & $0.28(0.05,0.53)^{*}$ & $0.09(-0.12,0.30)$ \\
\hline Aid received ${ }^{\mathrm{b}}$ & $0.22(-0.70,1.15)$ & $0.18(-0.91,1.26)$ \\
\hline Province $^{c}$ & $-0.61(-2.18,1.13)$ & $-0.60(-2.33,1.23)$ \\
\hline Gross income: province & $-0.43(-0.83,-0.10)^{*}$ & NS \\
\hline
\end{tabular}

Estimates are presented as posterior $\beta$ estimate and $95 \%$ credible interval $(\mathrm{Cl})$

* $\mathrm{Cl}$ does not cross zero

a Reference category is 'severely food insecure of access' (0), alternative is a higher classification of food security of access (1)

b Reference category for dichotomous variable is 'no' (0), alternative is 'yes' (1)

c Reference category is Yatenga province, alternative is Seno

Table 3 Household diet diversity (mixed-effects negative binomial regressions)

\begin{tabular}{|c|c|c|}
\hline & Lean period & Flush period \\
\hline Intercept & $1.25(1.00,1.51)^{*}$ & $1.97(1.74,2.20)^{*}$ \\
\hline Household head literacy ${ }^{a}$ & $0.06(-0.04,0.16)$ & $0.02(-0.05,0.10)$ \\
\hline Household head gender ${ }^{\mathrm{b}}$ & $0.09(-0.09,0.26)$ & $0.01(-0.15,0.13)$ \\
\hline Household inhabitants (adult eq.) & $0.01(-0.01,0.02)$ & $0.00(-0.01,0.01)$ \\
\hline Gross farm income ('000 USD year ${ }^{-1}$ ) & $0.01(-0.06,0.08)$ & $0.02(-0.01,0.04)$ \\
\hline Off-farm income earned ${ }^{\mathrm{a}}$ & $0.13(0.00,0.25)^{*}$ & $0.05(-0.04,0.14)$ \\
\hline Relative female control (>40\% income year ${ }^{-1}$ ) & $0.04(-0.15,0.23)$ & $-0.03(-0.17,0.12)$ \\
\hline Number of crop species & $0.05(0.01,0.09)^{*}$ & $0.01(-0.03,0.04)$ \\
\hline Number of livestock species & $0.00(-0.04,0.03)$ & $0.01(-0.01,0.04)$ \\
\hline Province $^{c}$ & $-0.30(-0.52,-0.08)^{*}$ & $-0.02(-0.25,0.22)$ \\
\hline Gross farm income: off-farm income earned & $0.02(-0.06,0.11)$ & NS \\
\hline Gross farm income: province & $-0.10(-0.19,-0.01)^{*}$ & NS \\
\hline Off-farm income earned: province & $0.07(-0.11,0.25)$ & NS \\
\hline Gross farm income: off-farm income earned: province & $0.16(0.04,0.28)^{*}$ & NS \\
\hline
\end{tabular}

Estimates are presented as posterior $\beta$ estimate and $95 \%$ credible interval $(\mathrm{Cl})$

* $\mathrm{Cl}$ does not cross zero

a Reference category for dichotomous variable is 'no' (0), alternative is 'yes' (1)

b Reference category is 'male', alternative is 'female'

c Reference category is Yatenga province, alternative is Seno

province, 'Roots and tubers' were incorporated in diets with greater diversity (Additional file 1: Fig. S2).

There were several statistically significant associations with diet diversity. Table 3 presents regression outputs for HDDS in both the 'lean' and 'flush' periods. In the 'lean' period there are interactions between gross farm income, off-farm income and province, which makes the associations difficult to interpret from the combination of coefficients; these interactions are best visualised as marginal effects. Figure 3 presents the associations between gross farm income and diet diversity in the 'lean' period. Gross farm income was positively associated with diet diversity 
Table 4 Summary of Household Diet Diversity Score (HDDS; median and IQR)

\begin{tabular}{llll}
\hline & Yatenga $(\mathbf{n}=\mathbf{2 0 0})$ & Seno $(\mathbf{n}=\mathbf{2 0 0})$ & Significance \\
\hline HDDS_lean period & $6.0(2.0)$ & $3.5(3.0)$ & $*$ \\
HDDS_flush period & $9.0(1.0)$ & $8.0(4.0)$ & NS \\
HDDS from farm production_lean period & $2.0(2.0)$ & $1.0(1.0)$ & $*$ \\
HDDS purchased_lean period & $6.0(2.0)$ & $3.0(3.0)$ & $*$ \\
HDDS from farm production_flush period & $3.0(2.0)$ & $3.0(2.0)$ & NS \\
HDDS purchased_flush period & $7.0(2.0)$ & $7.0(5.0)$ & N \\
\hline
\end{tabular}

*Provinces have differing central tendencies

a Observations with no purchased food in the 'lean' period removed ( $n=8$ from Yatenga province)

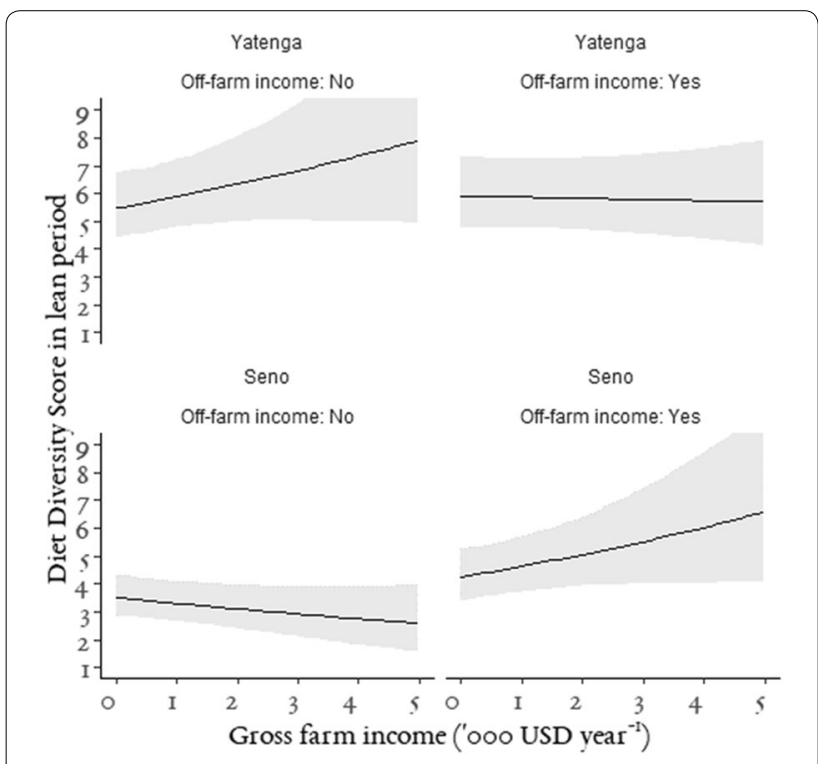

Fig. 3 Household Diet Diversity Score in the 'lean' period. Marginal effects of gross income ('000 USD) by off-farm income and province; grey area indicates uncertainty of marginal effect estimates at a 95\% credible interval

in Yatenga province in the 'lean' period, particularly for households that did not earn off-farm income. In Seno province these associations differ, where diet diversity in the 'lean' period is predicted to increase as gross farm income increases-only when off-farm income is also earned. Households that did not earn off-farm income in Seno province were predicted to decrease in diet diversity in the 'lean' period as gross farm income increased.

Crop species diversity was also positively associated with diet diversity in the 'lean' period-regardless of province. This statistically significant association, however, did not persist when assessing crop production diversity (count of crop products in HDDS categories) which, by definition, has a closer association with HDDS.

We also assessed whether: (a) the influence of farm income on diet diversity is mediated by female control; (b) food self-sufficiency is positively associated with diet diversity (variable removed from regression) and (c) wealth (PPI) is positively associated with diet diversity (variable removed from regression). However, female control of income, food self-sufficiency and wealth were not found to be associated with diet diversity in this study.

The channel of access of food categories provides a disaggregated view of HDDS. In both provinces and periods, purchased diversity was a greater point of differentiation than farm-sourced diversity (Table 4). The median number of purchased food categories was three times as much as own-farm sourced categories in the 'lean' period and more than double own-farm sourced categories in the 'flush' period. Households generally purchased at least one food category over the course of the year. In instances where income from crop sales was not earned, households earned income from livestock or off-farm sources. Farm-sourced categories were largely limited to the cereals and 'pulses, legumes and nuts' categories, with some households having the addition of vegetables, eggs, meat and/or milk (results not shown).

At the aggregate level, the own-farm channel of food access had a limited association with diet diversity. This is understandable, where in the 'lean' period, households tended to source only one or two food categories from their farm (Table 4). However, at the disaggregated level, the number of crop species cultivated is associated with diet diversity accessed through the own-farm channel in the 'lean' period (Table 5). In the 'flush' period, both the number of crop and livestock species were associated with diet diversity accessed through the own-farm channel. These associations persisted when assessing crop and livestock production diversity instead of species diversity (results not shown). The gender of household head and the number of household inhabitants was negatively associated with diet diversity sourced from the farm in the 'flush' period.

The pathway by which livestock species diversity is associated with diet diversity differs by site and period. 
Table 5 Household diet diversity accessed through ownfarm channel (mixed-effects negative binomial regression)

\begin{tabular}{llc}
\hline & Lean period & Flush period \\
\hline Intercept & $0.08(-0.54,0.69)$ & $0.71(0.30,1.12)^{*}$ \\
Household head literacy $^{\mathrm{a}}$ & $0.08(-0.08,0.24)$ & $0.03(-0.14,0.09)$ \\
Household head gender $^{\mathrm{b}}$ & $0.20(0.14,0.52)$ & $-0.27(-0.52,-0.03)^{*}$ \\
$\begin{array}{l}\text { Household inhabitants } \\
\quad \text { (adult eq.) }\end{array}$ & $0.00(-0.02,0.02)$ & $-0.02(-0.03,0.00)^{*}$ \\
Number of crop species $_{\text {Number of livestock species }}$ & $0.11(0.04,0.17)^{*}$ & $0.05(-0.00,0.10)^{*}$ \\
Nuvince $^{c}$ & $0.21(-0.51,0.94)$ & $0.23(-0.21,0.67)$
\end{tabular}

Estimates are presented as posterior $\beta$ estimate and $95 \%$ credible interval (CI)

* $\mathrm{Cl}$ does not cross zero

a Reference category for dichotomous variable is ' $n o$ ' (0), alternative is 'yes' (1)

b Reference category is 'male', alternative is 'female'

c Reference category is Yatenga province, alternative is Seno

In Yatenga province, livestock rearing facilitated the consumption of meat through the own-farm channel in the 'flush' period only. This meat was almost exclusively from goats and poultry. In Seno province, meat was sourced through the own-farm channel in both periods, with fewer households doing so in the 'lean' period. In the flush period, households in Seno slaughtered goats and poultry for meat, but in the 'lean' period, this was almost exclusively goats.

Milk was rarely sourced through the own-farm channel in Yatenga province, as only one sampled household produced it and only in the flush period. In Seno province, milk was sourced through the own-farm channel in both periods-with lower consumption levels in the 'lean' period. The difference in milk consumption from the own-farm channel is attributable to households either ceasing production $(22 \%$ of households that produced milk; results not shown) or having production decline by more than half (62\% of households producing milk; histogram presented in Additional file 1: Fig. S3).

At the disaggregated level, there is greater uncertainty around the interactions between purchased diet diversity, farm income, off-farm income and province (Table 6); the association between off-farm income and province persists, yet the interaction with farm income is no longer significant. At this disaggregated level we also see associations between household inhabitants and the number of crop species cultivated with purchased diet diversity in the 'lean' period. The association with the number of crop species cannot be considered causal as the ownfarm channel of food access is not represented in Table 6 . Rather, this result informs us that the purchased channel to diet diversity is not impeded by crop species diversity.

\section{Discussion}

Our analysis shows that in both provinces, the ability to purchase food is what differentiates the more food secure households from their less food secure counterparts. This finding does not detract from the utility of subsistence production-where consumption of own-farm food tended to cater for a large proportion of the annual energy requirements in Yantenga and Seno provinces (Table 1). Rather, purchasing power was the

Table 6 Household diet diversity accessed through purchased channel (mixed-effects negative binomial regression)

\begin{tabular}{|c|c|c|}
\hline & Lean period $^{\mathrm{a}}$ & Flush period \\
\hline Intercept & $1.23(0.98,1.47)^{*}$ & $1.82(1.48,2.13)^{*}$ \\
\hline Household head literacy ${ }^{a}$ & $0.03(-0.07,0.13)$ & $0.01(-0.07,0.09)$ \\
\hline Household head gender ${ }^{c}$ & $0.08(-0.12,0.26)$ & $0.02(-0.13,0.17)$ \\
\hline Household inhabitants (adult eq.) & $0.01(0.00,0.02)^{*}$ & $0.00(-0.01,0.01)$ \\
\hline Gross farm income ('O00 USD year' ${ }^{-1}$ ) & $0.00(0.00,0.01)$ & $0.00(0.00,0.00)$ \\
\hline Off-farm income earned ${ }^{b}$ & $0.11(0.00,0.23)^{*}$ & $0.04(-0.06,0.15)$ \\
\hline Relative female control ( $>40 \%$ calories year ${ }^{-1}$ ) & $0.02(-0.17,0.21)$ & $-0.07(-0.21,0.07)$ \\
\hline Number of crop species & $0.04(0.00,0.09)^{*}$ & $0.01(-0.02,0.05)$ \\
\hline Number of livestock species & $-0.02(-0.05,0.02)$ & $0.01(-0.07,0.09)$ \\
\hline Province $^{d}$ & $-0.36(-0.53,-0.18)^{*}$ & $0.00(-0.37,0.38)$ \\
\hline Off-farm income earned: province & $0.20(0.03,0.36)^{*}$ & NS \\
\hline
\end{tabular}

Estimates are presented as posterior $\beta$ estimate and $95 \%$ credible interval (Cl)

* $\mathrm{Cl}$ does not cross zero

a Observations with no purchased food in the 'lean' period removed ( $n=8$ from Yatenga province)

b Reference category for dichotomous variable is 'no' (0), alternative is 'yes' (1)

c Reference category is 'male', alternative is 'female'

${ }^{d}$ Reference category is Yatenga province, alternative is Seno 
differentiating factor between households with mere energy adequacy and those that have more nutritionally complete diets. This differentiation of households is most apparent in the dietary diversity indicator, where in both 'lean' and 'flush' periods, purchased food groups were more numerous than consumption of own-farm produced food groups (Table 4). This is logical in this setting where at maximum, households could source nine of the 12 categories from their farm (including processing oil); realistically, households were observed to source two to three categories from their farm in the 'flush' period (similar findings in [36]. These farm-sourced categories were largely limited to the cereals and 'pulses, legumes and nuts' categories. This finding is consistent with the majority of recent studies on the relative importance of purchased/farm-sourced foods [31-35, 37, 39]. Similarly, Jones [29], while emphasising the importance of diverse farm production across wealth strata, noted that the relationship between production diversity and diet diversity may be mediated through income generation (and thus purchased food), as well as farm-sourced food groups. With a growing consensus, can it then be concluded (as implicit in the aims of [40]) that food insecurity will be eradicated by doubling the agricultural productivity and incomes of small-scale producers' through onfarm means and off-farm employment/business? Food security is not simply limited to an individual's capacity to access calories. Other important dimensions of food security include: protein and micro-nutrient intake, resilient agricultural practices, maintaining genetic diversity of plants and animals, and maintaining access to culturally relevant foods [41]. Further, the allocation of scarce household resources is not solely dedicated to achieving food security. Households use their income to pursue multiple goals (e.g. education), and the allocation of resources depends on needs (including food security and other higher order needs) and complex intra-household dynamics [42, 43].

\section{Towards a pathway model of food security}

The potential pathways from food and income availability to food security analysed in this study are represented diagrammatically in Fig. 4. The diagram includes practice adoption and farm activities from Fig. 2 and Table 1 on the left-hand-side, representing the basis for food production. Both market and subsistence (own-farm) channels to food security are represented in a flow (indicated by arrows) from the left-hand side towards the right-hand side. Market participation and off-farm income both contribute to gross income. Mediated through expenditure, market participation and storage decisions, these two channels of food access (purchased and own-farm) then have a bearing on energy access, diversity of food access and food security more generally (right-hand-side of Fig. 4). The pathways from food and income availability to food security may also influence the pattern of food utilisation and food safety within a household. These dimensions of food security, however, are beyond the scope of this study (top right bullet points of Fig. 4).

The relationship between crop diversity and the diversity of food access is a central area of inquiry in the literature. Previous studies have used this relationship to draw conclusions on whether to reduce hidden hunger by supporting market-oriented interventions (upper drivers in Fig. 4) or by promoting agrobiodiversity (lower driver in Fig. 4). Our results suggest that these goals do

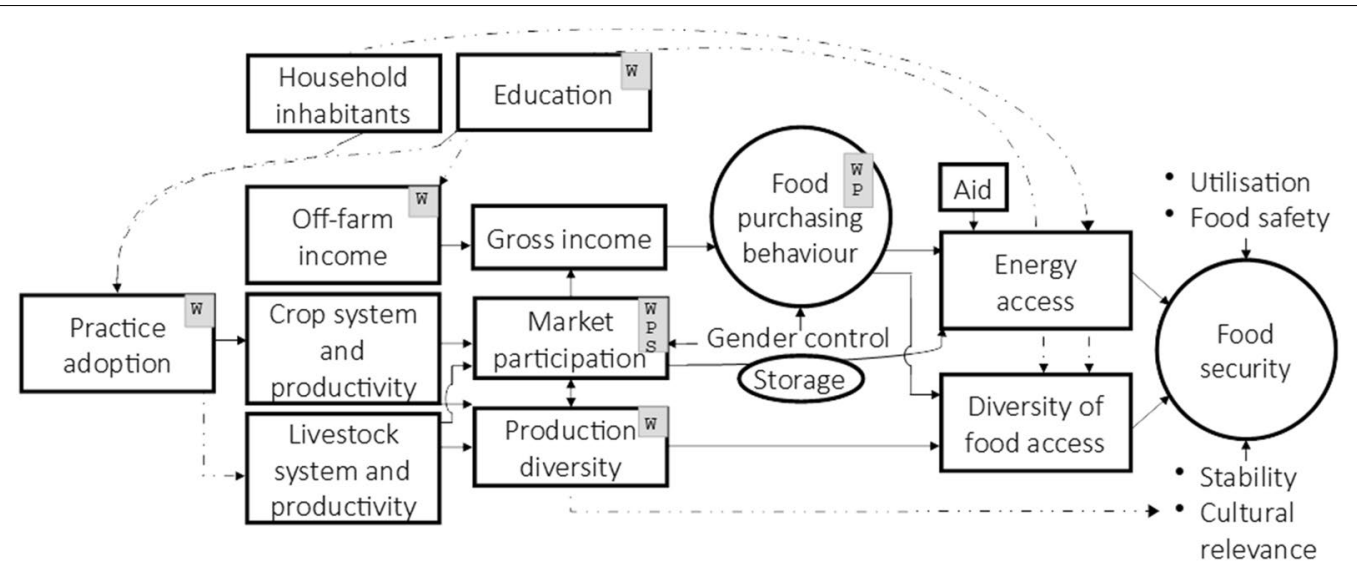

Fig. 4 Pathways to food security outcomes. Square boxes represent measured variables; round variables represent latent/unmeasured variables; solid arrows represent associations identified in this study; dotted arrow refers to a hypothesised association; 'W' indicates where wealth is hypothesised to influence; ' $P$ ' indicates where input or product price is hypothesised to influence; ' $S$ ' indicates where storage is hypothesised to influence. Adapted from [29] 
not have to be mutually exclusive. Both gross income and livestock species diversity, for example, are associated with improved food security of access. Similarly, gross farm income, crop species diversity and livestock species diversity were associated with more diverse diets. Considering the implications of this more generally, livestock keeping-as part of a diversified portfolio-provides soil health benefits through the recycling of nutrients, as well as reducing livelihood risk by acting as a means to store capital [44, 45]. Similarly, diversified crop production can contribute to pest and disease management, reduce the market risk of volatile prices, and can also be a part of a soil health strategy (e.g. nitrogen fixation or cover cropping to reduce erosion [46]. Each of these benefits can improve the resilience of a farm and a livelihood, specifically in relation to environmental or economic shocks-ultimately improving stability of food security status (represented by the dotted line between production diversity and stability in Fig. 4).

The majority of households cultivated sorghum and millet. Access to such culturally relevant and nutritious foods is not guaranteed in the future [11, 47, 48]. The global trend of increasing food homogeneity (e.g. [49] has already resulted in traditional, lower yielding grains such as tef (Eragrostis tef Zucc.), millet and sorghum being substituted with maize (Zea mays L.), traditional vegetables replaced with market vegetables, and narrowed livestock genetic resources. The potential trade-offs between energy availability, resilience and the availability of culturally relevant and nutritious foods need to be considered to be able to optimise all aspects of food security (represented by the dotted line between production diversity and cultural relevance in Fig. 4).

The 'income pathway' to improved food security has not been fully captured in all its complexity in this study. We observed significant differences in median crop income based on practice adoption. This relationship may be bi-directional, with higher incomes allowing practice adoption, and practice adoption increasing crop incomes. We also observed associations between gross income and food security (food security of access and diet diversity; Tables 3 and 4). These associations differed substantially by province and whether off-farm income was earned (in the case of diet diversity). In this study, however, we only identified an association between gender of head and diet diversity from the farm in the 'flush' period (Table 5). There was no such association between female control of income and food security-which by no means negates the reality that intra-household dynamics influence food access or food utilisation (e.g. [50].

Off-farm income was more common in Yatenga (67\% of households in Yatenga compared to 57\% in Seno), but proved to be a greater differentiating factor in Seno.
Having a wage or business income is an apparent advantage over a reliance on agriculture [51]. In Seno this advantage provides a pathway to a greater variety of food categories in the 'lean' period-when households are at their most vulnerable.

Aid (a potential driver of improved food security in Fig. 4) was received by a small portion of households in Yatenga province. There was no significant difference in food security status between recipients of aid and other respondents. This is not enough, however, to conclude whether this aid was effective in improving the food security of these households.

\section{Methodological considerations}

The stratified sampling of rural households in this study has allowed us to improve our understanding of the roles of home produced and purchased food in household level food security in two subtly contrasting communities in drought prone regions of Burkina Faso. There are, however, some methodological limitations to our approach. Firstly, the sampling of this study was limited to eight communities within seven departments with some departments of Yatenga province excluded from sampling due to safety concerns. Conflict has been identified as an important driver of food insecurity [52] and so the results of this study cannot be taken to be representative of northern Yatenga.

Secondly, we enumerated food security indicators and farm production/marketing based on respondent recall. The complexity and length of recall may have negatively impacted measurement precision and item non-response [53]. To counteract this, we designed the survey to minimise respondent fatigue and we trained enumerators to cross-check responses to more complex questions. These design features, unfortunately, did not enable us to enumerate the cost of crop production-which suffered from item non-response. An alternative approach would be to interview households in both the 'lean' and 'flush' periods, with the consequence of increased costs.

Thirdly, as identified by Some and Jones [36], we interviewed the household head on farm activitiespotentially underestimating production diversity and potentially misreporting gender control of income. An alternative implemented by other studies is to interview both the household head and their female/male counterpart (as implemented in the pro-WEAI and WEAI; [54, 55]. By interviewing both genders, researchers can generate an objective measure of gender equality-the Gender Parity Index.

There are a number of variables that are associated with food security and nutritional status more broadly. Household composition, education, wealth, product storage, input prices and market prices have an influence on 
livelihood decisions, livelihood outcomes, food availability and a household's ability to purchase food (incorporated in Fig. 4). Of these variables, we only included household inhabitants, literacy and wealth in our analysis; prices are factored into the income estimate. Product storage would be a useful addition in our assessment (incorporated in Fig. 4). The nutritional status of an individual is also affected by stability of food access, health status, food preparation and sanitation $[7,56]-$ limiting our results to food access outcomes. Furthermore, the stability of food security of access could be explored further by collecting monthly data on hypothesised covariates.

\section{Policy implications}

The global community is ambitiously aiming to realise 'zero hunger' by 2030. Concurrently, aid flows have stagnated, investment in agricultural research and development has been limited and the nature of the challenge is changing because food systems in Africa are transforming. To achieve 'zero hunger' in this context, policymakers must prioritise and target investment. Our results provide insights into in the fine scale needed when targeting rural households, as well as potential areas of investment.

The two sites in our study were subtly contrasting geographically, but significantly different in livelihood composition and food security status (Tables 1 and 4). This implies that policy and interventions need to be targeted at both agro-ecological conditions as well as socioeconomic factors-such as livelihood composition [57]. Policies on crop agricultural intensification may be most suited to households in Yatenga province where market participation is higher. Similarly, policies on dairy intensification may be more suited to Seno province. Such intensification policies can be implemented in tandem with initiatives that promote farm diversity and off-farm employment opportunities. The combination of policies can work to address both chronic and hidden hunger.

There are also opportunities to maintain or improve the stability and cultural relevance of food security. In the context of northern Burkina Faso, potential investments include: locally relevant breeding [34, 39], and extension activities that couple soil health education with fertiliserbased intensification programmes [58]. Plant breeding and soil health can work to optimise yields and micronutrient bioavailability (increasing translocation and reducing inhibition) of locally relevant crops $[59,60]$.

The demographic and food system transformations occurring across SSA have implications for the local labour markets [17, 61-63]. Ultimately, a smaller proportion of the population will be engaged in farming directly. From a policy and intervention perspective, there are macro-economic factors, regional comparative advantages and a range of other elements that drive the opportunities to engage in employment or business. Interventions to stimulate such opportunities can be targeted at specific regions or communities to improve household food security. A challenge that may arise in the process of stimulating off-farm opportunities, however, is that the individuals that capture them may not be the most in need; evidence suggests that wealthier households have a greater capacity to gain employment or invest in a non-farm business [51, 61, 64]. The complexities of the labour market are such that not only do the opportunities have to exist, but education options must be available and of high quality $[17,62]$ and land tenure, credit and insurance markets need to be fully functional [65].

\section{Conclusions}

The food security status of households is most substantially and positively influenced by a household's ability to purchase food. This finding should not detract from the essential role played by subsistence production. Rather, market-orientated agriculture and production for home consumption, as shown by households in this study, can be combined as part of a broader livelihood strategy. Such livelihood strategies can improve food access and the stability of food security in both the 'lean' and 'flush' periods.

\section{Methods}

\section{Household characteristics}

The two study areas are located in the Sudanian-Savanna and Sahelian zones of northern Burkina Faso. Soils in northern Burkina Faso generally have poor soil fertility and ongoing land degradation [66]. We selected Yatenga and Seno provinces as our study areas as both provinces are vulnerable to food insecurity and have subtly contrasting production potential and ethno-cultural backgrounds.

The prevalence of chronic malnutrition in Burkina Faso remains of concern. According to a nutritional survey conducted in the country in 2016, the national prevalence of chronic malnutrition was estimated to be $7.6 \%$ for all men, women and children (Ministry of Health and National Institute of Statistics and Demography (Burkina Faso) [67]). This prevalence varied across the country, with $8.2 \%$ of individuals in the region surrounding Yatenga identified as malnourished, and $7.9 \%$ in the region surrounding Seno. Chronic and hidden hunger are experienced most severely in the 'lean' period. The most food insecure period is during planting (typically June to August), where the 'lean' period typically extends from May to mid-August-with some variation across 
agro-ecological zones [36]. In general, diet diversity is lower in the Sudanian-Savanna and Sahelian zones compared the wider Burkina Faso (ibid.).

According to the Global Yield Gap Atlas [68], both provinces fall below their potential in terms of crop production. The rain-water limited yield potential in Yatenga was estimated to be 5.5 tonnes per hectare for sorghum and 2.7 tonnes per hectare for millet, with actual yields also estimated to be below one tonne per hectare. Water limited yield potential in Seno was 2.7 tonnes per hectare for sorghum and 1.3 tonnes per hectare for millet, with actual yields estimated to be below one tonne per hectare.

\section{Data}

As described in Ayantunde et al. [69], fifty households were randomly sampled from four communities in each region, totalling 400 households (Fig. 5). Communities were selected based on the following criteria: (i) representativeness (e.g. ethnicity, wealth, scale of production), (ii) population (at least 500 households), (iii) suitability for on-farm trials, and (iv) security risk (northern departments/communes in Yatenga were excluded on this basis). Focus group discussions were conducted in the eight communities, each including 20 to 25 participants. Households were then randomly sampled based on full lists of households-provided by the community leaders. Due to limitations on pre-existing data, sample size was set at 50 households per community-based on an approximate target of $5-10 \%$ of the population ([70], community household population is presented in Table 7). All selected households agreed to participate. The interview questions were developed based on objectives for the project and the research questions of this study. The questionnaire was pre-tested in each community to ensure the questions were properly framed. The
Table 7 Number of households by department and community

\begin{tabular}{lllc}
\hline Province & Department/commune & Community & $\begin{array}{c}\text { Households } \\
\text { in community }\end{array}$ \\
\hline Yatenga & Ouahigouya & Aorema & 751 \\
& & Bogoya & 1054 \\
& Namissiguima & Tougou & 893 \\
Seno & Oula & Ziga & 793 \\
& Bani & Bani & 1236 \\
& Dori & M'Bamga & 851 \\
& Gorgadji & Gorgadji & 987 \\
& Seytenga & Seytenga & 1106 \\
\hline
\end{tabular}

INSD [71, 72]

research design is this study allows us to evaluate the food access channels in two contrasting sites in Sudanian-Savanna and Sahelian zones.

Interviews took place prior to the month of Ramadan (where the month of fasting started on the 6th of June, 2016). The household head responded to the majority of questions and other household members were engaged on questions related to food security and diet diversity (e.g. the person who prepares the meals). Respondents were asked detailed questions on household demographics, plot utilisation, livestock holdings, crop yields, farm product utilisation, income, diet, food security, poverty level and labour allocation. Households were asked to recall circumstances from both the most food secure period and the least food secure period of the year (the periods of challenged food security are defined by respondent perceptions of scarcity and presented in the results).

The core indicators assessed in this study were based on standardised methodologies. Household Food Insecurity Access Prevalence (HFIAP) and Household Food
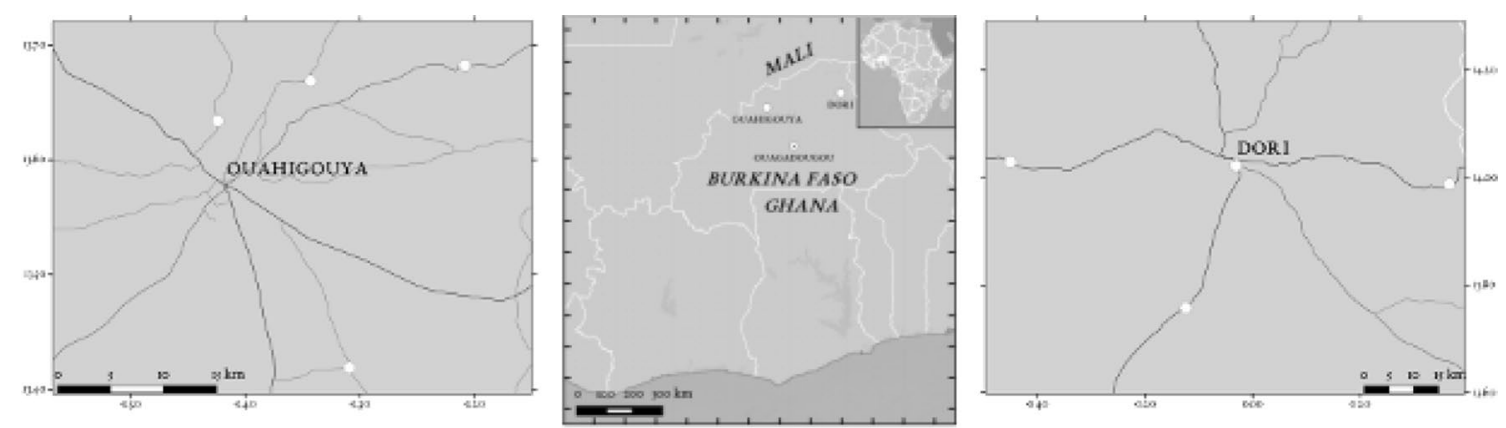

LEGEND

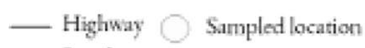

- Roud Capital aty

Fig. 5 Study areas and sampled communities (based of GADM and OSM data) 
Insecurity Access Scale (HFIAS) were calculated based on the nine food access questions from the 'Food And Nutrition Technical Assistance III' project (FANTA) guidelines [22], based on generalised recall of food access conditions in the 'flush' and 'lean' periods; the nine questions enumerate the severity of food insecurity, ranging from 'worry of food access' at one end of the scale, to decreased portion sizes and missed meals at the other extreme. Household Diet Diversity Scores (HDDS) were calculated using a 12 food category scale as detailed in the FANTA guidelines [73], based on recall of both periods. The recall period used in this study are an adaptation of existing guidelines, which suggest using 24-hour recall. This adaptation is designed to provide a more consistent metric-independent of the timing or duration of survey implementation. The 'flush' and 'lean' periods of the study were relative to the individual household, where a household could be 'food secure' but still report on the most 'lean' period in the year.

Several variables on the household were calculated for our analysis-including the number of inhabitants and nutritional adequacy ratios. Adult equivalents were calculated based on energy requirements relative to adult female and males (averaged) between 25 and 50 (2500 kcal based on energy requirements from FAO $[74,75]$. Energy adequacy ratios were calculated for home consumed crop and livestock products and protein adequacy ratios were calculated for livestock products only-based on food composition tables specific to west Africa [76]-and a coarse measure of minimum daily energy ( $2500 \mathrm{kcal}$ adult equivalent ${ }^{-1}$ day $^{-1}$ ) and protein requirements (56 g adult equivalent ${ }^{-1}$ day $^{-1}$ ).

Variables calculated to characterise the farm and livelihoods of rural households included: farm production diversity, livestock holdings, crop yields, market participation, income, cost of production, gendered control of income and wealth. Farm production diversity has been represented several different ways in the literature (e.g. species count in $[31,38]$, diet diversity aligned categories in $[29,32]$ and the debate between the approaches found in the dialogue between $[39,77]$. In the present study, the channel of HDDS categories (farm or purchased) was explicitly asked. We also included a measure of crop and livestock diversity (count of species) and production diversity scores (count of products in the HDDS categories). A limitation of the production diversity scores is that they do not capture transformed crop and livestock products (e.g. into fats/oils).

Livestock holdings were represented as tropical livestock units (TLUs; conversion factors from [78]. Yields for sorghum, millet and maize were calculated based on farmer reported harvest volumes and area planted. Crop market participation was represented as the proportion sold of the total calorific value of crops produced; livestock market participation was represented as the proportion sold of total protein produced from livestock products. Market participation was enumerated on a crop and livestock product bases, collecting information on total volume produced and the approximate proportion sold/consumed. The profitability of agricultural enterprises was calculated using respondent estimated gross income and cost of production (COP) values where possible (live animals and livestock products), otherwise gross income was reported (crops). Gendered control of income was represented as the percentage of total income that females have autonomous control over. Gendered control was enumerated on an employment, crop and livestock product bases, where all income from each employment activity or agricultural product produced was enumerated separately and aggregated to a percentage of total income. The Progress out of Poverty Index (PPI) was calculated from 10 country specific questions on ownership of assets, education and household composition [79]. Further information on many of these variables can be found in Hammond et al. [80].

Off-farm income was enumerated across five income categories, namely: formal salaried employment, nonfarm agribusiness trading, pension/remittances and farm labour. All other income was earned by from the farm through crop, livestock, forestry or aquaculture/fishery enterprises, or renting out land.

The cost of production for crops was impacted by item non-response. Due to the high instance of missing data (63\% of crops produced missing) it was not possible to impute these data. The result of this is that crop income is reported in this study as gross income, while livestock income is reported as net income.

\section{Statistical analysis}

We first assessed the association between crop income and the adoption of intensification practices. The analysis then proceeded with an assessment of the covariates of food security of access status (HFIAP), and on-farm and purchased channels of diet diversity. We assumed that food insecurity of access and diet diversity were directly associated with on-farm production and by off-farm food sourcing through purchases (i.e. excluding hunting and foraging). Regression models were built based upon the pathways identified in Jones [29]; Fig. 1), incorporating variables that could influence food purchasing behaviour and the means to source purchased or own-produced food.

Relationships between core indicators and independent variables were modelled using Bayesian regressions, with random effects from community groupings on the intercept. Differences between groups were also modelled 
using a specification equivalent to a t-test, but without assumptions of normality [81]. Logistic regressions were used to model HFIAP, with the least desirable food security outcome (severe food insecurity) as the reference category (Eq. 1).

$$
\begin{aligned}
y & \sim \operatorname{Bernoulli}(\pi) \\
\log i t(\pi) & =\log \left(\frac{1-\pi}{\pi}\right)=\alpha+X \beta \\
\alpha & =\alpha_{0}+\alpha_{c} \\
\alpha_{0} & \sim \operatorname{Student}-t(3,0,10), \\
\alpha_{c} & \sim \operatorname{Normal}\left(\mu, \sigma_{c}\right), \\
\sigma_{c} & \sim \operatorname{Student}-t(3,0,10), \\
\beta & \sim \operatorname{Normal}(0.5,1),
\end{aligned}
$$

where $y$ is a random binary variable that represents the occurrence of higher food security status or occurrence of severe food insecurity; $\pi$ is the probability of higher food security status; the intercept $(\alpha)$ is comprised of fixed effects $\left(\alpha_{0}\right)$ and random effects $\left(\alpha_{\mathrm{c}}\right)$ from the community; $X$ represents a vector of covariates; $\beta$ is a vector of response coefficients-specified by a prior distribution.

Household Diet Diversity Scores were modelled using negative binomial regressions, allowing us to account for the overdispersion in the HDDS variable (i.e. variation not equal to the mean; [82]; Eq. 2).

$$
\begin{aligned}
y & \sim \operatorname{NegativeBinomial}(\mu, \phi), \\
\log (\mu) & =\alpha+X \beta, \\
\alpha & =\alpha_{0}+\alpha_{c}, \\
\alpha_{0} & \sim \operatorname{Student}-t(3,2,10), \\
\alpha_{c} & \sim \operatorname{Normal}\left(0, \sigma_{c}\right), \\
\sigma_{c} & \sim \operatorname{Student}-t(3,0,10), \\
\beta & \sim \operatorname{Normal}(0.5,1), \\
\phi & \sim \operatorname{Gamma}(0.01,0.01)
\end{aligned}
$$

where $y$ is the count of diet diversity categories; $\mu$ is the probability of an increase in count; $\phi$ is the dispersion factor, representing the heterogeneity of counts due to latent correlations, estimated based on a gamma distribution; the intercept $(\alpha)$ is comprised of fixed effects $\left(\alpha_{0}\right)$ and random effects $\left(\alpha_{\mathrm{c}}\right)$ from the community; $X$ represents a vector of covariates; $\beta$ is a vector of response coefficients-specified by a prior distribution.

Regressions were weighted based on community populations to correct for over or under representation in some communities-i.e. the sum of weightings equated to the sample size for each province. A power analysis was conducted to assess the risk of type II errors. The power analysis indicated that the risk of a type II error was low (power $>0.99$ ) for comparisons of central tendency and regressions.

Priors for the beta coefficients were informed by field knowledge of the interaction of farm and household variables with food security. These prior distributions were informative to the extent that the explanatory variables were expected to be positively associated with food security; these priors were weakly informative in the sense that the ranges of plausible beta coefficients were not restricted. Normal distributions were used to this effect, with the mass of the prior distribution being centred to reflect a positive association (centred at 0.5 ), and a variance of one to allow for a greater range of plausible values. If for example, we were to use an exponential prior distribution on beta coefficients for HDDS we would constrain the posteriors to a floor of zero and an unconstrained upper ceiling. This could be reasonable if we are confident that the explanatory variables have a positive relationship with the dependent variable-however, we have not constrained the models in such a way.

Models were assessed against the Watanabe-Akaike Information Criterion (WAIC). Specifically, this means that if a variable is theorised to influence food security but is not significant in our models and not a confound, then we only retain it if the WAIC is minimised. Further, convergence was assessed using trace plots, and the model's output Rhat, with chains and iterations adjusted as necessary.

Regressions were implemented in R using the 'BRMS' package (v 1.0.1; [83]. The 'BRMS' package compiles Stan code (http://mc-stan.org/), which uses a hybrid MonteCarlo Markov Chain (MCMC) method to approximate the posterior distribution of the desired conditional probabilities. Thus the logistic regression models estimate the log odds of an observation being in the higher performing categories (i.e. not severely food insecure) as opposed to the poorest performing category (severely food insecure) given a unit change in an independent variable, with random effects at the community level; the negative binomial models estimate the log of the expected counts holding all else constant.

\section{Endogeneity}

There are multiple sources of potential endogeneity in assessing the associations with on-farm production, off-farm food sourcing and food security indicators. Measurement error is common in rural household surveys [84] and will have an attenuation bias on the relevant beta coefficients (i.e. potential type II error). Simultaneity (dependent variable influencing an independent variable) can result in overestimated beta coefficients (i.e. potential type I error) and inconsistency (i.e. estimates do not necessarily improve as sample 
size increases; [85]. Omitted variable bias (excluding variables that are associated with both dependent and independent variables) has the potential to introduce various biases. To address these sources of endogeneity, we minimised measurement error by using electronic data collection and minimising survey duration. We identified and assessed three key potential sources of simultaneity. We also incorporated all measured confounding variables into the model-controlling for known sources of omitted variable bias.

Sources of simultaneity in our models, could arise in three key instances: food insecurity resulting in outward migration, early crop harvest or destocking. Approximately $14 \%$ of households in the Sahelian zone earned income by panning for gold in the study period (largely non-livestock keepers and women). As such, strategic outward migration in the Sahelian zone is influenced by the price of gold. Gold prices declined to a 5 year low in November 2015, returning to the 5 year average price by May 2016. This indicates that there was not a strong incentive for outward migration in the study period; instead, it was observed that in the year prior to the present study, migrants were returning to the area to focus on farming-despite the poor climatic conditions [86].

In 2014-2015 it was reported that there was destocking of goats, sheep and poultry in the Sahel to finance the purchase of cereals and animal feed [86, 87]. Crop and pasture production was more favourable in 2015-2016the year which the present study reports on-resulting in average terms of trade for livestock keepers (FEWS, [88, 89]. As such, it is unlikely that the sampled households harvested crops early or sold livestock at unfavourable prices to meet short-term dietary needs.

\section{Supplementary information}

Supplementary information accompanies this paper at https://doi. org/10.1186/s40066-020-0255-z.

Additional file 1. Supplementary tables and figures.

\section{Abbreviations}

HFIAP: Household Food Insecurity of Access; HDDS: Household Diet Diversity Score; TLU: Tropical livestock unit; PPI: Progress out of Poverty Indicator; masl.: Metres above sea level; Cl: Credible interval; GADM: Global administrative areas; OSM: Open Street Maps.

\section{Acknowledgements}

We thank the field team for their dedication and the participating rural households for their candor.

\section{Authors' contributions}

$\mathrm{AA}$ and $\mathrm{MvW}$ designed the study, JH and MvW developed the survey tool, VY and AA coordinated the field activities, IJMdB, SJO, MvW, VY, AA, and JH provided substantial input into the manuscript, and SF processed, analysed and interpreted the data and led the manuscript writing process. All authors read and approved the final manuscript.

\section{Funding}

This study was made possible by the support of the American People provided to the Feed the Future Innovation Lab for Sustainable Intensification through the United States Agency for International Development (USAID). The contents are the sole responsibility of the authors and do not necessarily reflect the views of USAID or the United States Government. Program activities are funded by the United States Agency for International Development (USAID) under Cooperative Agreement No. AID-OAA-L-14-00006. Also support by the CGIAR Research Program on Livestock is gratefully acknowledged.

\section{Availability of data and materials}

The underlying data can be made available upon request to the corresponding author.

\section{Ethics approval and consent to participate}

This study conforms with the principles of the 1964 WMA declaration of Helsinki. Ethical approval for this study was obtained by the Internal Review Ethics Committee (IREC) of the International Livestock Research Institute.Survey participants were not particularly vulnerable, data was processed in anonymised form, and survey participants had the possibility to skip questions. Explicit oral informed consent was obtained from all survey participants prior to survey enumeration and documented as the opening survey upon informing survey participants of the study's purpose. If consent was denied, survey enumeration was terminated. Permission for obtaining oral rather than written consent from survey respondents was granted by the Internal Review Ethics Committee (IREC) of the International Livestock Research Institute, implementing research organisations and local agricultural officers, given literacy limitations among the target population.

\section{Consent for publication}

Not applicable, because there is no data contained within our manuscript from which individual patients or participants may be identified.

\section{Competing interests}

The authors declare that they have no conflict of interest.

\section{Author details}

${ }^{1}$ International Livestock Research Institute (ILRI), Naivasha Road, PO Box 30709, Nairobi 00100, Kenya. ${ }^{2}$ Animal Production Systems group, Wageningen University \& Research, P.O. Box 338, 6700 AH Wageningen, The Netherlands. ${ }^{3}$ International Livestock Research Institute (ILRI), BP 1496, Ouagadougou, Burkina Faso.

Received: 15 November 2019 Accepted: 19 March 2020

Published online: 26 May 2020

\section{References}

1. FAO, IFAD, UNICEF, WFP, WHO. The State of Food Security and Nutrition in the World 2019 Safeguarding against economic slowdowns and downturns. Rome: FAO; 2019.

2. Joy EJM, Ander EL, Young SD, Black CR, Watts MJ, Chilimba ADC, Chilima B, Siyame EWP, Kalimbira AA, Hurst R, Fairweather-Tait SJ, Stein AJ, Gibson RS, White PJ, Broadley MR. Dietary mineral supplies in Africa. Physiol Plant. 2014;151:208-29. https://doi.org/10.1111/ppl.12144.

3. Green R, Sutherland J, Dangour AD, Shankar B, Webb P. Global dietary quality, undernutrition and non-communicable disease: a longitudinal modelling study. BMJ Open. 2016. https://doi.org/10.1136/bmjop en-2015-009331.

4. Local Burden of Disease Child Growth Failure Collaborators. Mapping child growth failure across low- and middle-income countries. Nature. 2020;577:231-4. https://doi.org/10.1038/s41586-019-1878-8.

5. de Pee S, Taren D, Bloem MW, editors. Nutrition and health in developing world. 3rd ed. New York: Humana Press; 2017.

6. Carletto C, Corral P, Guelfi A. Agricultural commercialization and nutrition revisited: empirical evidence from three African countries. Food Policy. 2017:67:106-18. https://doi.org/10.1016/j.foodpol.2016.09.020.

7. von Braun J. Agricultural commercialization: impacts on income and nutrition and implications for policy. Food Policy. 1995;20:187-202. 
8. Hoddinott J. Agriculture, health, and nutrition: toward conceptualizing the linkages. Reshaping agriculture for nutrition and health. Washington, DC: International Food Policy Research Institute; 2012. p. 13-20. https:// doi.org/10.2499/9780896296732.

9. Kennedy E, Bouis $\mathrm{H}$, von Braun J. Health and nutrition effects of cash crop production in developing countries: a comparative analysis. Soc Sci Med. 1992;35:689-97.

10. McDermott J, Johnson N, Kadiyala S, Kennedy G, Wyatt AJ. Agricultural research for nutrition outcomes-rethinking the agenda. Food Secur. 2015;7(3):593-607. https://doi.org/10.1007/s12571-015-0462-9.

11. Schipanski ME, MacDonald GK, Rosenzweig S, Chappell MJ, Bennett EM, Kerr RB, Blesh J, Crew T, Drinkwater L, Lundgren JG, Schnarr C. Realizing resilient food systems. Bioscience. 2016;66(7):600-10. https://doi. org/10.1093/biosci/biw052.

12. OECD. 2015 Global aid prospects and projections. Paris: OECD; 2015.

13. Pardey PG, Chan-Kang C, Dehmer SP, Beddow JM. Agricultural R\&D is on the move. Nature. 2016;537:301-3. https://doi.org/10.1038/537301a.

14. NCD Risk Factor Collaboration. Rising rural body-mass index is the main driver of the global obesity epidemic in adults. Nature. 2019;569:260-4. https://doi.org/10.1038/s41586-019-1171-x.

15. Popkin BM, Corvalan C, Grummer-strawn LM. Dynamics of the double burden of malnutrition and the changing nutrition reality. Lancet. 2019;395:4-10. https://doi.org/10.1016/s0140-6736(19)32497-3.

16. Tschirley D, Reardon T, Dolislager M, Snyder J. The rise of a middle class in east and southern Africa: implications for food system transformation. J Int Dev. 2015;27:628-46. https://doi.org/10.1002/jid.3107.

17. Tschirley D, Snyder J, Dolislager M, Reardon T, Haggblade S, Goeb J, Traub L, Ejobi F, Meyer F. Africa's unfolding diet transformation: implications for agrifood system employment. J Agribus Dev Emerg Econ. 2015. https:// doi.org/10.1108/jadee-01-2015-0003.

18. Carletto C, Zezza A, Banerjee R. Towards better measurement of household food security: harmonizing indicators and the role of household surveys. Glob Food Secur. 2013;2:30-40. https://doi.org/10.1016/j. gfs.2012.11.006.

19. Santeramo FG. Development in Practice Food security composite indices: implications for policy and practice. Dev Pract. 2015;25:594-600. https:// doi.org/10.1080/09614524.2015.1029439.

20. Santeramo FG. On the composite indicators for food security: decisions matter! Food Rev Int. 2015. https://doi.org/10.1080/87559129.2014.96107 6.

21. Arimond M, Ruel MT. Community and international nutrition dietary diversity is associated with child nutritional status: evidence from 11 demographic and health surveys 1, 2. J Nutr. 2004;134:2579-85.

22. Coates J, Bilinsky P. Household Food Insecurity Access Scale (HFIAS) for measurement of food access: indicator guide. Washington, DC; 2007.

23. Rah JH, Akhter N, Semba RD, de Pee S, Bloem MW, Campbell AA, Moench-Pfanner R, Sun K, Badham J, Kraemer K. Low dietary diversity is a predictor of child stunting in rural Bangladesh. Eur J Clin Nutr. 2010;64(12):1393-8. https://doi.org/10.1038/ejcn.2010.171.

24. Saha KK, Frongillo E, Alam DS, Arifeen SE, Persson L, Rasmussen KM. Household food security is associated with growth of infants and young children in rural Bangladesh. Public Health Nutr. 2009;12(9):1556-62. https://doi.org/10.1017/s1368980009004765.

25. Savy M, Martin-Prével Y, Sawadogo P, Kameli Y, Delpeuch F. Use of variety/diversity scores for diet quality measurement: relation with nutritional status of women in a rural area in Burkina Faso. Eur J Clin Nutr. 2005:59:703-16. https://doi.org/10.1038/s.ejcn.1602135.

26. Steyn NP, Nel JH, Nantel G, Kennedy G, Labadarios D. Food variety and dietary diversity scores in children: are they good indicators of dietary adequacy? Public Health Nutr. 2006;9(5):644-50. https://doi.org/10.1079/ phn2005912.

27. Torheim LE, Ouattara F, Diarra MM, Thiam FD, Barikmo I, Hatløy A, Oshaug A. Nutrient adequacy and dietary diversity in rural Mali: association and determinants. Eur J Clin Nutr. 2004;58(4):594-604. https://doi. org/10.1038/sj.ejcn.1601853.

28. McDonald CM, McLean J, Kroeun H, Talukder A, Lynd LD, Green TJ. Household food insecurity and dietary diversity as correlates of maternal and child undernutrition in rural Cambodia. Eur J Clin Nutr. 2015;69:1-5. https ://doi.org/10.1038/ejcn.2014.161.

29. Jones AD. On-farm crop species richness is associated with household diet diversity and quality in subsistence- and market-oriented farming households in Malawi. J Nutr. 2016. https://doi.org/10.3945/ jn.116.235879.

30. Powell B, Thilsted SH, Ickowitz A, Termote C, Sunderland T, Herforth A. Improving diets with wild and cultivated biodiversity from across the landscape. Food Secur. 2015. https://doi.org/10.1007/s1257 1-015-0466-5.

31. Bellon MR, Ntandou-bouzitou GD, Caracciolo F. On-farm diversity and market participation are positively associated with dietary diversity of rural mothers in Southern Benin, West Africa. PLOS ONE. 2016;11(9):120. https://doi.org/10.1371/journal.pone.0162535.

32. Koppmair S, Kassie M, Qaim M. Farm production, market access and dietary diversity in Malawi. Public Health Nutr. 2016. https://doi. org/10.1017/s1368980016002135.

33. Luckett BG, DeClerck FA, Fanzo J, Mundorf AR, Rose D. Application of the Nutrition Functional Diversity indicator to assess food system contributions to dietary diversity and sustainable diets of Malawian households. Public Health Nutr. 2015;18(4):1-9. https://doi.org/10.1017/ s136898001500169x.

34. Sibhatu KT, Krishna VV, Qaim M. Production diversity and dietary diversity in smallholder farm households. Proc Natl Acad Sci USA. 2015. https://doi.org/10.1073/pnas.1510982112.

35. Snapp SS, Fisher M. "Filling the maize basket" supports crop diversity and quality of household diet in Malawi. Food Secur. 2015;7(1):83-96. https://doi.org/10.1007/s12571-014-0410-0.

36. Some JW, Jones AD. The influence of crop production and socioeconomic factors on seasonal household dietary diversity in Burkina Faso. PLOS ONE. 2018;13(5):1-16. https://doi.org/10.1371/journal.pone.01956 85.

37. Dillon A, Mcgee K, Oseni G. Agricultural Production, Dietary Diversity, and Climate Variability. J Dev Stud. 2014;51(8):975-95. https://doi. org/10.1080/00220388.2015.1018902.

38. M'Kaibi FK, Steyn NP, Ochola S, Du Plessis L. Effects of agricultural biodiversity and seasonal rain on dietary adequacy and household food security in rural areas of Kenya. BMC Public Health. 2015;15:422. https ://doi.org/10.1186/s12889-015-1755-9.

39. Sibhatu KT, Krishna VV, Qaim M. Reply to Berti: Relationship between production and consumption diversity remains small also with modified diversity measures. Proc Natl Acad Sci USA. 2015;112(42):5657. https://doi.org/10.1073/pnas.1517209112.

40. FAO. Can smallholders double their productivity and incomes by 2030? (No. 16-4). Rome. 2016. http://www.fao.org/3/a-i5959e.pdf. Accessed 12 Feb 2017.

41. FAO. An introduction to the basic concepts of food security. 2008. Social Indicators Research (Vol. 95). Rome; https://doi.org/10.1007/ s11524-010-9491-z.

42. Galiè A, Mulema A, Mora Benard MA, Onzere SN, Colverson KE. Exploring gender perceptions of resource ownership and their implications for food security among rural livestock owners in Tanzania, Ethiopia, and Nicaragua. Agric Food Secur. 2015;4(1):2. https://doi.org/10.1186/ s40066-015-0021-9.

43. Kazianga $\mathrm{H}$, Wahhaj Z. Intra-household resource allocation and familial ties. J Dev Econ. 2017;127:109-32. https://doi.org/10.1016/j.jdeve Co.2017.03.002

44. Moll HAJ. Costs and benefits of livestock systems and the role of market and nonmarket relationships. Agric Econ. 2005;32(2):181-93. https ://doi.org/10.1111/j.0169-5150.2005.00210.x.

45. Slingerland, M. Mixed farming: scope and constraints in West African Savanna. Wageningen University. 2000. http://search.ebscohost.com/ login.aspx?direct=true\&db=lah\&AN=20001811677\&site=ehost-live.

46. Lin BB. Resilience in agriculture through crop diversification: adaptive management for environmental change. BioScience. 2011;61(3):18393. https://doi.org/10.1525/bio.2011.61.3.4.

47. Pingali P. Agricultural policy and nutrition outcomes—getting beyond the preoccupation with staple grains. Food Secur. 2015;7(3):583-91. https://doi.org/10.1007/s12571-015-0461-X.

48. Remans R, Wood SA, Saha N, Lee T, Defries RS. Measuring nutritional diversity of national food supplies. Glob Food Secur. 2014;3(3-4):17482. https://doi.org/10.1016/j.gfs.2014.07.001.

49. Khoury CK, Bjorkman AD, Dempewolf $\mathrm{H}$, Ramirez-Villegas J, Guarino L, Jarvis A, Rieseberg LH, Struik PC. Increasing homogeneity in global food 
supplies and the implications for food security. Proc Natl Acad Sci USA. 2014;111(11):4001-6. https://doi.org/10.1073/pnas.1313490111.

50. Mason R, Ndlovu P, Parkins JR, Luckert MK. Determinants of food security in Tanzania: gendered dimensions of household headship and control of resources. Agric Hum Values. 2015;32(3):539-49. https://doi.org/10.1007/ s10460-014-9568-5.

51. Reardon T, Delgado C, Matlon P. Determinants and effects of income diversification amongst farm households in Burkina Faso. J Dev Stud. 1992;28(2):264-96. https://doi.org/10.1080/00220389208422232.

52. FAO, IFAD, UNICEF, WFP, WHO. The State of Food Security and Nutrition in the World 2018. Building climate resilience for food security and nutrition. Rome: FAO; 2018.

53. Beegle K, Carletto C, Himelein K. Reliability of recall in agricultural data. J Dev Econ. 2012;98(1):34-41. https://doi.org/10.1016/j.jdeve co.2011.09.005.

54. Alkire S, Malapit H, Meinzen-Dick R, Peterman A, Quisumbing A, Seymour $G$, Vaz A. Instructional guide on the women's empowerment in agriculture index. World Dev. 2013;52:71-91.

55. Malapit H, Quisumbing A, Meinzen-Dick R, Seymour G, Martinez EM, Heckert J, Rubin D, Vaz A, Yount KM. Development of the project-level Women's Empowerment in Agriculture Index (pro-WEAI). World Dev. 2019;122:675-92. https://doi.org/10.1016/..worlddev.2019.06.018.

56. Gödecke T, Stein AJ, Qaim M. The global burden of chronic and hidden hunger: trends and determinants. Glob Food Secur. 2018;17:21-9. https:// doi.org/10.1016/j.gfs.2018.03.004.

57. Fraval S, Hammond J, Bogard JR, Ng M, van Etten J, Herrero M, Oosting SJ, de Boer IJM, Skirrow T, Steinke J, Stirling CM, Yameogo V, Ng'endo M, Herrero M, Oosting SJ, de Boer IJM, Lannerstad M, Teufel N, Lamanna C, Rosenstock TS, Pagella T, Vanlauwe B, Dontsop-Nguezet PM, Baines D, Carpena P, Njingulula P, Okafor C, Wichern J, Ayantunde A, Bosire C, Chesterman S, Kihoro E, Rao EJO, Skirrow T, Steinke J, Stirling CM, Yameogo V van Wijk MT. Food Access Deficiencies in Sub-saharan Africa: prevalence and implications for agricultural interventions. Front Sustain Food Syst. 2019;3:104. https://doi.org/10.3389/fsufs.2019.00104.

58. Fonte SJ, Vanek SJ, Oyarzun P, Parsa S, Quintero DC, Rao IM, Lavelle P. Pathways to agroecological intensification of soil fertility management by smallholder farmers in the andean highlands. Advances in agronomy, vol. 116. 1st ed. Burlington: Elsevier Inc; 2012. p. 125-84. https://doi. org/10.1016/b978-0-12-394277-7.00004-х.

59. de Valença AW, Bake A, Brouwer ID, Giller KE. Agronomic biofortification of crops to fight hidden hunger in sub-Saharan Africa. Glob Food Secur. 2017;12:8-14. https://doi.org/10.1016/.j.gfs.2016.12.001

60. Slingerland MA, Traore K, Kayodé APP, Mitchikpe CES. Fighting Fe deficiency malnutrition in West Africa: an interdisciplinary programme on a food chain approach. NJAS Wageningen J Life Sci. 2006;53(3-4):253-79. https://doi.org/10.1016/s1573-5214(06)80009-6.

61. Haggblade S, Hazell P, Reardon T. The rural non-farm economy: prospects for growth and poverty reduction. World Dev. 2010;38(10):1429-41. https ://doi.org/10.1016/j.worlddev.2009.06.008.

62. Jayne TS, Chamberlin J, Headey DD. Land pressures, the evolution of farming systems, and development strategies in Africa: a synthesis. Food Policy. 2014;48:1-17. https://doi.org/10.1016/j.foodpol.2014.05.014.

63. Tiffen M. Transition in Sub-Saharan Africa: agriculture, urbanization and income growth. World Dev. 2003;31(8):1343-66. https://doi.org/10.1016/ s0305-750x(03)00088-3.

64. Davis B, Winters P, Carletto G, Covarrubias K, Quiñones EJ, Zezza A, Stamoulis K, Azzarri C, DiGiuseppe S. A cross-country comparison of rural income generating activities. World Dev. 2010;38(1):48-63. https://doi. org/10.1016/j.worlddev.2009.01.003.

65. Barrett $\mathrm{CB}$, Reardon T, Webb P. Nonfarm income diversification and household livelihood strategies in rural Africa: concepts, dynamics, and policy implications. Food Policy. 2001;26(4):315-31. https://doi. org/10.1016/s0306-9192(01)00014-8.

66. Turner MD. Assessment through socioecological abstraction: the case of nutrient management models in Sudano-Sahelian West Africa. Land Use Policy. 2018. https://doi.org/10.1016/j.landusepol.2018.09.034

67. Ministry of Health (Burkina Faso), National Institute of Statistics and Demography (Burkina Faso). Burkina Faso National Nutrition Survey 2016. 2016.

68. Global Yield Gap Atlas. Global Yield Gap Atlas. 2016. http://yieldgap.org/. Accessed 12 Sept 2017.
69. Ayantunde AA, Oluwatosin BO, Yameogo V, van Wijk MT. Perceived benefits, constraints and determinants of sustainable intensification of mixed crop and livestock systems in the Sahelian zone of Burkina Faso intensification of mixed crop and livestock systems in the Sahelian zone of Burkina Faso. Int J Agric Sustain. 2020;18(1):84-98. https://doi. org/10.1080/14735903.2019.1698494.

70. Lapan SD, Quartaroli MT, Riemer FJ. (Eds.). Qualitative research: an introduction to methods and designs (1st ed.). San Francisco: Jossey-Bass. 2011.

71. INSD. La région du Sahel en chiffres. Institut national de la statistique et de la démographie. 2018a. Ministère de l'Economie et des Finances, Burkina Faso. 8 pages.

72. INSD. La région du Nord en chiffres. Institut national de la statistique et de la démographie. 2018b Ministère de l'Economie et des Finances, Burkina Faso. 8 pages.

73. Swindale A, Bilinsky P. Household Dietary Diversity Score (HDDS) for measurement of household food access: indicator guide. Washington, DC. 2006.

74. FAO. Human energy requirements: Report of a Joint FAO/WHO/UNU Expert Consultation. 2001. http://www.fao.org/3/a-y5686e.pdf. Accessed 20 Mar 2017.

75. Claro, Rafael M, Levy RB, Bandoni DH, Mondini L. Per capita versus adultequivalent estimates of calorie availability in household budget surveys. Cad Saude Publica. 2010;26(11):2188-95.

76. FAO. Table de composition des aliments d'Afrique de I'Ouest West African Food Composition Table. Rome. 2012.

77. Berti PR. Relationship between production diversity and dietary diversity depends on how number of foods is counted. Proc Natl Acad Sci USA. 2015;112(42):1. https://doi.org/10.1073/pnas.1517006112.

78. Njuki J, Poole J, Johnson N, Baltenweck I, Pali P, Lokman Z, Mburu S. Gender. Nairobi: Livestock and Livelihood Indicators; 2011.

79. Schreiner M. Simple Poverty Scorecard ${ }^{\circledR}$ Poverty-Assessment Tool Burkina Faso. 2011. http://www.simplepovertyscorecard.com/BFA_2003_ENG.pdf. Accessed 7 Feb 2017.

80. Hammond J, Fraval S, van Etten J, Suchini JG, Mercado L, Pagella T, Frelat R, Lannerstad M, Douxchamps S, Teufel N, Valbuena D, van Wijk MT. The Rural Household Multi-Indicator Survey (RHoMIS) for rapid characterisation of households to inform climate smart agriculture interventions: description and applications in East Africa and Central America. Agric Syst. 2016;151:225-33. https://doi.org/10.1016/j.agsy.2016.05.003.

81. Kruschke JK. Bayesian estimation supersedes the $t$ test. J Exp Psychol Gen. 2013;142(2):573-603. https://doi.org/10.1037/a0029146.

82. McElreath R. Multi-level models. Statistical rethinking: a Bayesian course with examples in R and Stan. 1st ed. Boca Raton: Chapman and Hall/CRC; 2016. https://doi.org/10.3102/1076998616659752.

83. Buerkner, PC. Package "brms". 2016.

84. Fraval S, Hammond J, Wichern J, Oosting SJ, de Boer IJM, Teufel N, Lannerstad M, Waha K, Pagella T, Rosenstock T, Giller KE, Herrero M, Harris $D$, van Wijk MT. Making the most of imperfect data: a critical evaluation of standard information collected in farm household surveys. Exp Agric. 2018. https://doi.org/10.1017/s0014479718000388.

85. Verbeek M. A guide to modern econometrics. Hoboken: Wiley; 2012.

86. FEWS. Average harvests to stabilize the food security situation. 2014. https://fews.net/west-africa/burkina-faso/food-security-outlook/octob er-2014. Accessed 3 May 2016.

87. FEWS. Extreme north of the country facing Stressed acute food insecurity. 2015a. https://fews.net/west-africa/burkina-faso/food-security-outlook/ january-2015. Accessed 3 May 2016.

88. FEWS. Average 2015 harvests likely to result in Minimal (IPC Phase 1) acute food insecurity. 2015b. https://fews.net/west-africa/burkina-faso/ food-security-outlook/october-2015. Accessed 3 May 2016.

89. FEWS. Normal lean season is expected through September. 2016. https:// fews.net/west-africa/burkina-faso/food-security-outlook/february-2016. Accessed 3 May 2016

\section{Publisher's Note}

Springer Nature remains neutral with regard to jurisdictional claims in published maps and institutional affiliations. 